\title{
Effects Of Maytenus Senegalensis (L) and Cassia Alata (L) Extracts on the Liver Enzymes of Albino Rats, Infected with Schistosomes Cercariae
}

\author{
${ }^{*}$ DOMO, GA; ${ }^{1}$ KELA, SL; ${ }^{2}$ PANDA, SM; ${ }^{2}$ SAMAILA, AB \\ ${ }^{* 1}$ Federal University of Kashere, Gombe State, Nigeria \\ ${ }^{2}$ Abubakar Tafawa Balewa University, Bauchi. Bauchi State, Nigeria \\ *Corresponding Author Email: domogalbert@yahoo.co.uk Tel: +234 8069195219)
}

\begin{abstract}
This reaearch aim was to evaluate some liver enzymes of albino rats subjected to administration of methanol and water extracts of Maytenus senegalensis and Cassia alata after infection with schistosome cercariae. As curative agents, the extracts were well tolerated by rats. The total protein $(69.0-77.9 \mathrm{~g} / \mathrm{l}$ and $71.8-79.1 \mathrm{~g} / \mathrm{l})$ for methanolic extracts of and (64.3-74.3g/l and 70.3- 77.5g/l) for water extracts for M. senegalensis and C. alata respectively. The Alkaline phosphate values range from(145-226iu/l and 189-207iu/l) for methanol and (143-234iu/l and195-207iu/l) for water as for M. senegalensis and C. alata extracts. The Aspartate aminotransferase values were (7.7-8.7iu/l) for M. senegalensis and (8.08.6iu/l) for $C$. alata with methanol extraxts and (7.1-8.8iu/1) for M. senegalensis and (8.4-8.9iu/) for C. alata water extracts. The Alkaline aminotransferase values range from (5.1-6.3iu/l) for M. senegalensis and (3.5-6.4iu/l) for $C$. alata in methanol and (4.2-6.3iu/l) for $M$. senegalensis and (4.1-6.4iu/l for $C$. alata with water extracts. The Total Bilirubin values of both methanol and water extracts for $M$. senegalensis $(6.3-18.9 \mu \mathrm{m} / 1)$ and $(9.0-12.7 \mu \mathrm{m} / 1)$ for $C$. alata and $(4.2-6.3 \mu \mathrm{m} / 1)$ for $M$.

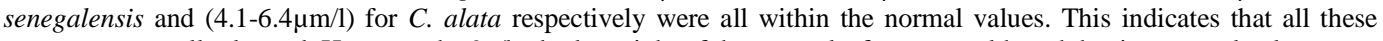
extracts were well tolerated. However the $9 \mathrm{~g} / \mathrm{kg}$ body weight of the water leaf extracts, although having normal values were toxic to other organs such as the lungs.
\end{abstract}

DOI: https://dx.doi.org/10.4314/jasem.v25i7.11

Copyright: Copyright $(92021$ Domo et al. This is an open access article distributed under the Creative Commons Attribution License (CCL), which permits unrestricted use, distribution, and reproduction in any medium, provided the original work is properly cited.

Dates: Received: 10 May 2021; Revised: 28 June 2021; Accepted: 01 July 2021

Keywords: Schistosoma, Maytenus senegalensis, Cassia alata, Albino rats, Liver enzymes

Schistosomiasis, is a disease caused by digenetic trematodes of the genus Schistosoma. Mortality due to this parasitic helminth disease is also estimated at 20,000 due bladder cancer, renal failure as for Schistosoma haematobium infection and liver fibrosis and portal hypertension as in the case $S$. mansoni. There are over 800 million people exposed to the risk of getting the infection spread over 77 countries (WHO, 2013). It was further estimated that 18 million people suffered bladder wall pathology and 10 million others were with hydronephrosis (WHO, 2013). In africa and other affected countries schistosomiasis is associated with agriculcural and other rural activities around the freshwater bodies, (John et al, 2008 and Shurrock, 2001). Schistosomiasis affects the health and the economy of infected population by reducing their ability to work (WHO, 2010) and infected people are generally poor and may not have the resources to afford the cost of modern treament and generally rely on traditional medicine (Mohammed et al. 2007). The potential for the development of resistance by schistosomes to PZQ was highlighted in 1995 by its apparently low efficacy when used to treat a newly established focus of Schistosoma mansoni in Senegal
(Stelma et al.1995). The use of these plants by humans in curing severals ailments poses undoubtedly some problems since doses of such of preparations could not be determined. It is also necessary to investigate their therapeuthic effects as well as the level of their toxicity to humans. It is for this purpose that Maytenus senegalensis and Cassia alata had been selected. This work is aimed at screening two medicinal plants as anti-schistosomal agents namely Cassia alata and Maytenus senegalensis and studying their effects on the biochemicals parameters of the host organism . The specific objectives are to screen and evaluate the potencial effects of these plants used by traditional herbalists in the body's liver enzymes using laboratory rats as indicators. To compare the properties of the various extracts of the plants using methanol and water as the extracting solvents.

\section{MATERIALS AND METHODS}

Collection of Plant materials, Snails and Schistosome eggs: The two plants Maytenus senegalensis and Cassia alata, were collected and were identified based on the characteristics of the leaves, flowers, fruits, stem- bark, Stanfield and Hopkins (1966), Hutchinson 
and Dalziel (1968). The useful parts of each of the plants (leaves, seed and roots) were washed and dried under shade in the greenhouse. Each part was then separately pounded using a wooden mortar and pestle and then sieved through ordinary flour sieve of mesh size of $0.30 \mathrm{~mm}$ and the powder from each was separately stored in labelled air tight polyethene bags until required for use. Bulinus snails were collected and kept into clean medium size aquarium, measuring $30 \times 45 \times 30 \mathrm{~cm}$ filled to $2 / 3$ capacity with de-ionized water. The de-ionized water was changed forthnightly to reduce pollution. Urine samples were collected from out patients ftom clinics and examined for eggs of schistosomes. Stool samples were immediately processed by the keto-kartz method and before being filtered using Wattman No.2 filter paper.

Collection, Rearing and Infection of Rats with Schisyosome Cercariae: Albino Winstar rats used in the experiments were purchased from the National Institute for Trypanosomiasis Research (NITR), Vom, Plateau State, Infected snails were exposed to strong electric light.. The cercariae are shedded in the container were allowed to penetrate each of the rats, by paddling method.

Formulation, Administration of Praziquantel and of Plant Materials: The standard anti-schistosomal drug Praziquantel tablets formulated $60 \mathrm{mg}$, Batch No. 121257, Nafdac Reg. No. A4-4246 manufactured by Yanzhou Xier Kangtai Pharmaceutical Co., Ltd. China and marked by Chez Resources Pharm were purchased and used. The drug was administered orally as single dose of $600 \mathrm{mg} / \mathrm{kg}$ of body weight as recommended by WHO (1980). The quantity of Praziquantel given to each rat was obtained by using the following formulation:

$$
\text { Weight of PZQ }(\mathrm{mg})=\frac{600 \mathrm{mg} \times \mathrm{Wt}_{a n}(\mathrm{mg})}{1000 \mathrm{mg}}
$$

Where $\mathrm{Wt}_{\mathrm{an}}=$ weight of animal

After the treatment, a period of 10-14 days was accorded, after which animals were sacrificed for examination of the therapeutic effect of the drug.

Similarly, plant materials were weighted following the same procedure as above. Thereafter a single oral dose of various concentrations was administered to each rat using stomach gavage using the same formular:

$$
\mathrm{WPE}(\mathrm{mg})=\frac{(\mathrm{A}) \mathrm{mg} \times \mathrm{Wt}_{a n}(\mathrm{mg})}{1000 \mathrm{mg}}
$$

Where WPE = Weight of Plant extract
Where (A) represents the dose: 3,6 or $9 \mathrm{~g} / \mathrm{kg}$ body weight

Statistical Analysis: Statistical analyzes were performed using the Fisher's test for contingency analysis and the student independent t-test. These analyzes were performed using the Statistical Package for Social Sciences software (SPSS 17.0, Chicago, IL, USA). Continuous variables were expressed as means \pm standard deviation (SD) of the median and range. Pvalues of less than 0.05 were considered statistically significant.

\section{RESULTS AND DISCUSSION}

The lowest and highest values of the biochemical parameters of some of the liver enzymes such as total protein (TPT); serum albumin (SAL); alkaline phosphate (ALP); aspartate aminotransferase (AST); alanine aminotransferase (ALT), total bilirubin (TBB), creaine and Urea and other liver enzymes in treated rats were determined. Results obtained are shown in Tables 1.

Total Protein Count: For the roots of Maytenus senegalensis (Table 1), the highest average count in the methanolic extract for the total protein (TPT) was $71.4 \mathrm{~g} / \mathrm{l}$ recorded in rats treated with $3 \mathrm{~g} / \mathrm{kg}$ body weight of the extracts. The lowest average count of $69.0 \mathrm{~g} / \mathrm{l}$ was recorded in those treated with $9 \mathrm{~g} / \mathrm{kg}$ body weight dose. For the acqueous water extracts, the highest value of $66.7 \mathrm{~g} / \mathrm{l}$ was found in rats treated with $6 \mathrm{~g} / \mathrm{kg}$ body weight while the lowest value of $64.3 \mathrm{~g} / \mathrm{l}$ was in those treated with $3 \mathrm{~g} / \mathrm{kg}$ body weight. In the methanolic leaves extracts of $M$. senegalensis, the average highest count of $77.9 \mathrm{~g} / \mathrm{l}$ was recorded in rats treated at a dose of $3 \mathrm{~g} / \mathrm{kg}$ body weight, while the lowest value of $77.5 \mathrm{~g} / \mathrm{l}$ was found in those treated with $9 \mathrm{~g} / \mathrm{kg}$ body weight dose. The highest value for the water extracts was $74.3 \mathrm{~g} / \mathrm{l}$ recorded when the rats were administered the $3 \mathrm{~g} / \mathrm{kg}$ body weight of the extract. Its lowest value of $70.7 \mathrm{~g} / \mathrm{l}$ was in the $6 \mathrm{~g} / \mathrm{kg}$ body weight treated group.

For the methanolic extracts of stem-bark of $M$. senegalensis, the average highest protein count of 72.8 $\mathrm{g} / \mathrm{l}$ was recorded in rats given $3 \mathrm{~g} / \mathrm{kg}$ body weight of extracts, while the lowest value of $71.1 \mathrm{~g} / \mathrm{l}$ was in those given $6 \mathrm{~g} / \mathrm{kg}$ body weight. For the water extracts, on the other hand, the highest value of $71.2 \mathrm{~g} / 1$ was obtained in rts treated with $6 \mathrm{~g} / \mathrm{kg}$ body weight while the lowest value of $68.6 \mathrm{~g} / \mathrm{l}$ was obtained in $3 \mathrm{~g} / \mathrm{kg}$ body weight group. For the methanolic extracts of the leaves of Cassia alata, the average highest count of $79.9 \mathrm{~g} / \mathrm{l}$ was recorded in the rats treated with $9 \mathrm{~g} / \mathrm{kg}$ body weight of the extracts with the lowest value of $71.8 \mathrm{~g} / \mathrm{l}$ recorded in those treated with $6 \mathrm{~g} / \mathrm{kg}$ body 
weight. In the water extracts of $C$. alata, the highest average value of the total protein was $77.5 \mathrm{~g} / \mathrm{l}$ recorded in rats treated with $9 \mathrm{~g} / \mathrm{kg}$ body weight of the leaves extracts of the plant with the lowest value of $70.3 \mathrm{~g} / 1$ in rats treated with $3 \mathrm{~g} / \mathrm{kg}$ body weight of the extracts. For the methanolic extracts of seeds of Cassia alata, the average highest total protein ccount value of 79.0 $\mathrm{g} / \mathrm{l}$ was recorded in the $3 \mathrm{~g} / \mathrm{kg}$ body weight rats, while the lowest value of $74.9 \mathrm{~g} / \mathrm{l}$ was obtained in rats treated with $9 \mathrm{~g} / \mathrm{kg}$ body weight. The highest average value for the water extracts, was $75.0 \mathrm{~g} / 1$ in rats treated with
$6 \mathrm{~g} / \mathrm{kg}$ body weight while the lowest average value of $70.3 \mathrm{~g} / \mathrm{l}$ was in those treated with $9 \mathrm{~g} / \mathrm{kg}$ body weight extracts groups. These differences are not significant stsistically $(\mathrm{P} \leq 0.05)$. Frances (2002), Amir Al-Hroob (2010), and Abdel-Ghaffar, et al. (2005) reported that the total protein values of schistosomiasis decreases in chronic infections. This observation contradicts reports of blood chemistry of earlier reports on blood chemistry of Schistosoma mansoni in infected rats (Abdel-Hadi and Talaat, 2000); that showed a reduction in the total serum protein.

Table 1: Biochemical changes in Schistosome infected treated rats with various plant extracts and Praziquantel

\begin{tabular}{|c|c|c|c|c|c|c|c|c|c|c|c|c|c|c|}
\hline 善 & 量 & 气ิ & \multicolumn{6}{|c|}{$\begin{array}{l}\text { Methanol } \\
\text { Parameters }\end{array}$} & \multicolumn{6}{|c|}{$\begin{array}{c}\text { Water } \\
\text { Parameters }\end{array}$} \\
\hline \multirow{7}{*}{ 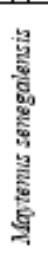 } & & $3 \mathrm{~g} / \mathrm{kg}$ & 71.4 & 49.6 & 145 & 7.7 & 5.8 & 6.3 & 64.3 & 47.6 & 143 & 7.1 & 5.5 & 8.0 \\
\hline & 实 & $9 \mathrm{~g} / \mathrm{kg}$ & 69.0 & 49.8 & 175 & 7.7 & 4.7 & 8.4 & 66.5 & 49.4 & 178 & 7.9 & 5.7 & 8.6 \\
\hline & a & $3 \mathrm{~g} / \mathrm{kg}$ & 77.9 & 51.3 & 181 & 8.2 & 5.9 & 13.5 & 74.3 & 45.6 & 168 & 7.7 & 5.8 & 12.3 \\
\hline & 氧 & $6 \mathrm{~g} / \mathrm{kg}$ & 77.8 & 37.3 & 214 & 8.2 & 5.1 & 10.6 & 70.7 & 37.9 & 211 & 8.8 & 4.2 & 8.7 \\
\hline & 窞 & $6 \mathrm{~g} / \mathrm{kg}$ & 71.1 & 49.7 & 226 & 8.5 & 4.8 & 11.8 & 70.7 & 48.1 & 213 & 8.8 & 5.5 & 10.1 \\
\hline & 幽 & $9 \mathrm{~g} / \mathrm{kg}$ & 71.8 & 51.4 & 206 & 8.7 & 5.3 & 11.8 & 71.2 & 47.7 & 216 & 8.4 & 5.7 & 11.8 \\
\hline & 4 & $3 \mathrm{~g} / \mathrm{kg}$ & 71.8 & 51.1 & 202 & 8.6 & 3.5 & 10.9 & 70.3 & 48.3 & 206 & 8.7 & 4.6 & 10.4 \\
\hline \multirow{3}{*}{ 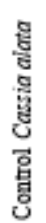 } & 莺 & $6 \mathrm{~g} / \mathrm{kg}$ & 76.1 & 52.2 & 200 & 8,1 & 6.4 & 9.5 & 77.3 & 50.4 & 195 & 8.4 & 6.4 & 9.0 \\
\hline & ติ & $9 \mathrm{~g} / \mathrm{kg}$ & 79.1 & 50.0 & 196 & 8.0 & 6.4 & 9.0 & 77.5 & 50.3 & 207 & 8.4 & 5.7 & 10.4 \\
\hline & & $3 \mathrm{~g} / \mathrm{kg}$ & 79.0 & 48.9 & 207 & 8.5 & 5.7 & 12.5 & 74.5 & 48.2 & 206 & 8.4 & 6.2 & 10.4 \\
\hline
\end{tabular}

Total Seum Albumin Count: For rats treated with extracts from the roots of Maytenus senegalensis, as shown in Table 1, the highest average count of total serum albumin count in the rats treated with methanolic extracts was $49.8 \mathrm{~g} / \mathrm{l}$ recorded in those given $9 \mathrm{~g} / \mathrm{kg}$ body weight of the extracts, while the lowest average count of $49.3 \mathrm{~g} / \mathrm{l}$ was recorded in those treated with $6 \mathrm{~g} / \mathrm{kg}$ body weight dose. For acqueous the water extracts on the other hand, the highest value of $49.4 \mathrm{~g} / \mathrm{l}$ was found in the group of rats treated with a dose of $9 \mathrm{~g} / \mathrm{kg}$ body weight. The corresponding lowest of $46.7 \mathrm{~g} / \mathrm{l}$ was obtained in those treated with $6 \mathrm{~g} / \mathrm{kg}$ body weight dosage. For the methanolic leaf extracts of $M$. senegalensis, the average highest count the total serum albumin of $51.3 \mathrm{~g} / \mathrm{l}$ was recorded in rats treated with $3 \mathrm{~g} / \mathrm{kg}$ body weight, while the lowest value of 37.2 $\mathrm{g} / \mathrm{l}$ was found in the group given $9 \mathrm{~g} / \mathrm{kg}$ body weight concentration of the extracts. In the water extracts, the highest average value was $45.6 \mathrm{~g} / \mathrm{l}$ also in the given $3 \mathrm{~g} / \mathrm{kg}$ body weight concentration of the extracts. The lowest value of the total serum albumin of $37.9 \mathrm{~g} / \mathrm{l}$ was in the $6 \mathrm{~g} / \mathrm{kg}$ body weight treated groups. For the methanolic extracts of the stem-bark of $M$. senegalensis, the average highest count of $51.4 \mathrm{~g} / \mathrm{l}$ was recorded in eats treated with $9 \mathrm{~g} / \mathrm{kg}$ body weight, while the lowest value of $49.7 \mathrm{~g} / \mathrm{l}$ was obtained in rats given $6 \mathrm{~g} / \mathrm{kg}$ body weight. In the water extracts on the other hand, the highest average value was $48.1 \mathrm{~g} / 1$ recorded in the $6 \mathrm{~g} / \mathrm{kg}$ body weight rats while the lowest value of $47.6 \mathrm{~g} / \mathrm{l}$ was in the rats givem $3 \mathrm{~g} / \mathrm{kg}$ body weight dose. For the methanolic leaves extracts of Cassia alata, the average highest value count of the total serum albumin of $52.2 \mathrm{~g} / \mathrm{l}$ was recorded in rats treated with $6 \mathrm{~g} / \mathrm{kg}$ body weight of extracts, while the lowest value of $50.0 \mathrm{~g} / \mathrm{l}$ in those given $9 \mathrm{~g} / \mathrm{kg}$ body weight. In the corresponding water extracts, the highest average count was in $50.4 \mathrm{~g} / \mathrm{l}$ recorded in rats both administered with the $6 \mathrm{~g} / \mathrm{kg}$ body weight, while the lowest value of $48.3 \mathrm{~g} / \mathrm{l}$ was in the $3 \mathrm{~g} / \mathrm{kg}$ body weight group. For the methanolic seed extracts of Cassia alata, the average highest count of total serum albumin was $53.7 \mathrm{~g} / \mathrm{l}$ recorded in rats treated with $9 \mathrm{~g} / \mathrm{kg}$ body weight of extracts, while the lowest value of $48.9 \mathrm{~g} / \mathrm{l}$ was in those rats in the $3 \mathrm{~g} / \mathrm{kg}$ body weight treated groups. The highest average count was of $51.7 \mathrm{~g} / \mathrm{l}$ for the water extracts was in rats dosed with the $9 \mathrm{~g} / \mathrm{kg}$ body weight with the lowest value of $48.3 \mathrm{~g} / \mathrm{l}$ in those treated with $3 \mathrm{~g} / \mathrm{kg}$ body weight.. ANOVA test revealed that these differences are not significant statistically ( $\mathrm{P} \leq 0.05)$. According to Frances (2002), the serum albumin increases with intravenous infusion or dehydration which may not be the case in this research work. The high value of serum albumin in the infected non-treated rats could have be due high 
intensity of the infection. Similar observations were made by Hamadto et al. (1990).

Alaline Phosphate Count: For the roots of Maytenus senegalensis (Table 1) the highest average count in the methanolic extracts for the alkaline phosphate (ALP) was $186 \mathrm{iu} / \mathrm{l}$ recorded from rats treated with $6 \mathrm{~g} / \mathrm{kg}$ body weight of extracts, while the lowest average count $145 \mathrm{iu} / \mathrm{l}$ was recorded in those in the $3 \mathrm{~g} / \mathrm{kg}$ body weight treated group. For the acqueous water extracts, the highest value of 179iu/l was found in rats treated with $6 \mathrm{~g} / \mathrm{kg}$ body weight of extracts, while the lowest value of $143 \mathrm{iu} / \mathrm{l}$ was in those given $3 \mathrm{~g} / \mathrm{kg}$ body weight dosage. For the methanolic leaf extracts of $M$. senegalensis, the average highest alkaline phosphate count of $214 \mathrm{iu} / \mathrm{l}$ was recorded in the $6 \mathrm{~g} / \mathrm{kg}$ body weight treated rats , while the lowest value of 181iu/l was found in those treated with $3 \mathrm{~g} / \mathrm{kg}$ body weight. In the water extracts, the highest average value was 234 $\mathrm{iu} / \mathrm{l}$ in the $9 \mathrm{~g} / \mathrm{kg}$ body weight treated rats with, the lowest value of $168 \mathrm{iu} / 1$ recorded in those treated with $3 \mathrm{~g} / \mathrm{kg}$ body weight. For the methanolic extracts from stem-bark of $M$. senegalensis, the average highest count was $226 \mathrm{iu} / \mathrm{l}$ recorded in rats treated with $6 \mathrm{~g} / \mathrm{kg}$ body weight of extracts, while the lowest value of 206 $\mathrm{iu} / \mathrm{l}$ was in those given dose of $9 \mathrm{~g} / \mathrm{kg}$ body weight. For the water extracts, the highest average count was $216 \mathrm{iu}$ $/ 1$ in rats treated both with $3 \mathrm{~g} / \mathrm{kg}$ and $9 \mathrm{~g} / \mathrm{kg}$ body weight while the lowest value of $213 \mathrm{iu} / 1$ in those rats treated with $6 \mathrm{~g} / \mathrm{kg}$ body weight dose of extracts. In the methanolic leaf extract of Cassia alata, the average highest count of alkaline phosphate was $202 \mathrm{iu} / 1$ recorded in rats in the $3 \mathrm{~g} / \mathrm{kg}$ body weight treated groups, while the lowest value of $196 \mathrm{iu} / \mathrm{l}$ was found in those treated with $9 \mathrm{~g} / \mathrm{kg}$ body weight. For the water extracts, the highest average count was $207 \mathrm{iu} / 1$ recorded in the $9 \mathrm{~g} / \mathrm{kg}$ body weight group while the lowest value of $195 \mathrm{iu} / \mathrm{l}$ in the $6 \mathrm{~g} / \mathrm{kg}$ body weight treated groups. For the methanolic extracts of the seeds of Cassia alata, the average highest alkaline phosphate count value of $207 \mathrm{iu} / 1$ was recorded in rats of the $3 \mathrm{~g} / \mathrm{kg}$ body weight treated groups, while the lowest value of $189 \mathrm{iu} / \mathrm{l}$ was in the $9 \mathrm{~g} / \mathrm{kg}$ body weight category. The highest average value for those in the water extracts was $206 \mathrm{iu} \mathrm{g} / \mathrm{l}$ in rats dosed with both $3 \mathrm{~g} / \mathrm{kg}$ and $9 \mathrm{~g} / \mathrm{kg}$ body weight of extracts. The lowest count was of $203 \mathrm{iu} / \mathrm{l}$ recorded in the $6 \mathrm{~g} / \mathrm{kg}$ body weight dose groups. ANOVA test revealed that the differences in these mean counts are not significant ( $P$ $\leq 0.05$ ). The values of alkaline phosphotase (ALP) obtained in this work were all below the ranges. These results further showed that there was no statistical difference at $\mathrm{P} \geq 0.05$.

Aspartate Aminotransferase Count: The average counts for aspartate aminotransferase for both treated experimentally and the control counts are shown in Table1. For the roots, the highest average count for rats in the methanolic extracts of Maytenus senegalensis is $8.0 \mathrm{iu} / 1$ recorded in those rats given $6 \mathrm{~g} / \mathrm{kg}$ body weight dose of the extracts, while the lowest average count of $7.7 \mathrm{iu} / 1$ was recorded in those given both $3 \mathrm{~g} / \mathrm{kg}$ and $9 \mathrm{~g} / \mathrm{kg}$ body weight doses. For acqueous water extract, the highest value of $8.3 \mathrm{iu} / 1$ was found in rats treated with $6 \mathrm{~g} / \mathrm{kg}$ body weight while the lowest value of $7.1 \mathrm{iu} / 1$ was in the $3 \mathrm{~g} / \mathrm{kg}$ body weight treated groups. In the methanolic leaf extracts of $M$. senegalensis, the average highest count of 8.2 $\mathrm{iu} / \mathrm{l}$ in the groups given either $3 \mathrm{~g} / \mathrm{kg}$ or $6 \mathrm{~g} / \mathrm{kg}$ body weight of extracts. The lowest value of $8.0 \mathrm{iu} / 1$ was found in the $9 \mathrm{~g} / \mathrm{kg}$ body weight group. For the water extracts, the highest average count was $8.8 \mathrm{iu} / 1$ for rats treated with $6 \mathrm{~g} / \mathrm{kg}$ body weight dose the lowest mean value of $7.7 \mathrm{iu} / \mathrm{l}$ was obtained in the $3 \mathrm{~g} / \mathrm{kg}$ body weight treated rats. For those in methanolic extracts of the stem-bark of $M$. senegalensis, the average highest count of $8.5 \mathrm{iu} / \mathrm{l}$ was recorded in the $9 \mathrm{~g} / \mathrm{kg}$ body weight treated rats, while the lowest value of $7.8 \mathrm{iu} / 1$ was in those given either $3 \mathrm{~g} / \mathrm{kg}$ or $6 \mathrm{~g} / \mathrm{kg}$ body weight doses. The corresponding value for the water extracts had the highest average count of $8.8 \mathrm{iu} / 1$ in the $6 \mathrm{~g} / \mathrm{kg}$ body weight treated rats, while the lowest value of $7.7 \mathrm{iu} / 1$ in those dosed with $3 \mathrm{~g} / \mathrm{kg}$ body weight concentration of the extracts. In case of the methanolic extracts from the leaves of Cassia alata, the average highest aspartate aminotransferase count of $8.6 \mathrm{iu} / 1$ was recorded in the $3 \mathrm{~g} / \mathrm{kg}$ body weight treated rats, while the lowest value of $8.0 \mathrm{iu} / \mathrm{l}$ was the group of rats given extracts dose of $9 \mathrm{~g} / \mathrm{kg}$ body weight. In the corresponding water extracts, the highest average count was $8.7 \mathrm{iu} / 1$ recorded in rats given $3 \mathrm{~g} / \mathrm{kg}$ body weight. The lowest value was $8.4 \mathrm{iu} / 1$ obtained in rats given either $6 \mathrm{~g} / \mathrm{kg}$ or $9 \mathrm{~g} / \mathrm{kg}$ body weight doses of the plant extracts. For the rats subjected to the methanolic extracts of the seeds of Cassia alata, the average highest aspartate aminotransferase count value of 8.6 $\mathrm{iu} / \mathrm{l}$ was recorded in the $6 \mathrm{~g} / \mathrm{kg}$ body weight group, while the lowest value of $8.4 \mathrm{iu} / \mathrm{l}$ was in the $9 \mathrm{~g} / \mathrm{kg}$ body weight treated group. For the water extracts, the highest average count was $8.9 \mathrm{iu}$ g/l obtained in the $9 \mathrm{~g} / \mathrm{kg}$ body weight treated group and the lowest value of $8.4 \mathrm{iu} / \mathrm{l}$ in the $3 \mathrm{~g} / \mathrm{kg}$ body weight dose category. The values are not significant statistically as revealed by ANOVA test $(\mathrm{P} \leq 0.05)$. All the results in this research fall within the normal values including the infected non-treated rats. Several reports including Hamalto et al., (1990), Amir Al-hrooth (2000) and WHO, (2003) confirmed the similar trends which all agreed with the results in this investigation.

Alkaline Aminotransferase: For the roots of Maytenus senegalensis as shown in Table 1, the highest average 
of alkaline aminotransferase (ALT) count in rats treated with methanolic extracts was $6.7 \mathrm{iu} / \mathrm{l}$ recorded those treated with both $6 \mathrm{~g} / \mathrm{kg}$ and $9 \mathrm{~g} / \mathrm{kg}$ body weight of the extracts, while the lowest average count of 5.8 $\mathrm{iu} / \mathrm{l}$ was recorded in the $3 \mathrm{~g} / \mathrm{kg}$ body weight treated groups. For the acqueous water extracts, the highest value was $6.7 \mathrm{iu} / \mathrm{l}$ obtained from rats treated with $9 \mathrm{~g} / \mathrm{kg}$ body weight group, while the lowest count of $5.5 \mathrm{iu} / 1$ in the $3 \mathrm{~g} / \mathrm{kg}$ body weight treated groups. For the methanolic leaf extracts of $M$. senegalensis, the average highest alkaline aminotransferase count of 7.2 $\mathrm{iu} / \mathrm{l}$ was recorded in the $9 \mathrm{~g} / \mathrm{kg}$ body weight treated rats, while the lowest value of $5.9 \mathrm{iu} / 1$ was found in the $3 \mathrm{~g} / \mathrm{kg}$ body weight group. In case of the water extracts, the highest average count was $7.2 \mathrm{iu} / 1$ in the group of rats treated with $6 \mathrm{~g} / \mathrm{kg}$ body weight with the lowest value of $5.8 \mathrm{iu} / \mathrm{l}$ obtained in those given $3 \mathrm{~g} / \mathrm{kg}$ body weight dose of the extracts. The trend of the alkaline aminotransferase count for rats treated methanolic extracts of the stem-bark of $M$. senegalensis revealed that the average highest count of $7.8 \mathrm{iu} / 1$ was recorded in rats dosed with $6 \mathrm{~g} / \mathrm{kg}$ body weight, while the lowest value of $6.7 \mathrm{iu} / \mathrm{l}$ was recorded in the $3 \mathrm{~g} / \mathrm{kg}$ body weight treated groups. For the water extracts, on the other hand, the highest average value is $8.5 \mathrm{iu} / \mathrm{l}$ obtained in the $6 \mathrm{~g} / \mathrm{kg}$ body weight dose group. The lowest alkaline aminotransferas count of $6.7 \mathrm{iu} / \mathrm{l}$ was in those given dose of both the $3 \mathrm{~g} / \mathrm{kg}$ and $9 \mathrm{~g} / \mathrm{kg}$ body weight of the extracts. For the methanolic leaf extracts of Cassia alata, the average highest count was $7.5 \mathrm{iu} / 1$ obtained in rats dosed with $3 \mathrm{~g} / \mathrm{kg}$ body weight with the lowest of value of $6.4 \mathrm{iu} / 1$ recorded in rats given doses of $6 \mathrm{~g} / \mathrm{kg}$ and $9 \mathrm{~g} / \mathrm{kg}$ body weight of extracts group. The corresponding water extracts, treated rats had the highest average alkaline aminotransferase value of 7.7 $\mathrm{iu} / \mathrm{l}$ recorded in those administered $9 \mathrm{~g} / \mathrm{kg}$ body weight while the lowest value of $6.4 \mathrm{iu} / \mathrm{l}$ was in the $6 \mathrm{~g} / \mathrm{kg}$ body weight treatment group. For the methanolic extracts from the seeds of Cassia alata, the average highest count value was $10.7 \mathrm{iu} / 1$ was recorded in rats dosed with $3 \mathrm{~g} / \mathrm{kg}$ body weight concentration of the extracts, while the lowest value of $8.2 \mathrm{iu} / \mathrm{l}$ was in the $6 \mathrm{~g} / \mathrm{kg}$ body weight group. The highest value for those in the water extracts, was $8.3 \mathrm{iu} \mathrm{g} / \mathrm{l}$ in the group given $6 \mathrm{~g} / \mathrm{kg}$ body weight with the lowest value of $8.1 \mathrm{iu} / 1$ recorded in the $9 \mathrm{~g} / \mathrm{kg}$ body weight treated group. Similar analysis of the differences by use of ANOVA revealed that these differences are not significant satistically $(\mathrm{P} \leq$ 0.05). The normal values of Alkaline aminotransferase (ALT) in albino rats vary from 1.4-1.6 u/l (Giknis and Clifford, 2008). The values obtained in this research work with some few exceptions are all above the normal limits according to Frances (2002), the ALT increases in hepatocellular disease, hepatis, liver tumor etc. The high values observed could be attributed to the liver disease caused by schistosomiasis.

Total Bilirubin Count: For the roots of Maytenus senegalensis as shown in Table 1, the highest average total bilirubin count for the rats treated with methanolic extracts was $18.9 \mathrm{iu} / \mathrm{l}$ recorded in the $6 \mathrm{~g} / \mathrm{kg}$ body weight treated group, while the lowest average count of $6.3 \mathrm{iu} / \mathrm{l}$ was recorded in the $3 \mathrm{~g} / \mathrm{kg}$ body weight group. For the acqueous water extracts on the othe hand, the highest value of $19.0 \mathrm{iu} / 1$ was found in rats in the $6 \mathrm{~g} / \mathrm{kg}$ body weight group, while the lowest value of $8.0 \mathrm{iu} / 1$ was in those given $3 \mathrm{~g} / \mathrm{kg}$ body weight dose. For those in the methanolic extracts of the leaves of $M$. senegalensis, the average highest total bilirubin count of $13.5 \mathrm{iu} / \mathrm{l}$ was recorded in the both $3 \mathrm{~g} / \mathrm{kg}$ and $6 \mathrm{~g} / \mathrm{kg}$ body weight treated rats, while the lowest value of 8.3 $\mathrm{iu} / \mathrm{l}$ in the $9 \mathrm{~g} / \mathrm{kg}$ body weight treated group. In the water extracts, the highest average total bilirubin count was $14.4 \mathrm{iu} / 1$ recorded in the $9 \mathrm{~g} / \mathrm{kg}$ body weight treated rats with the lowest of count of $8.7 \mathrm{iu} / 1$ in the group given $6 \mathrm{~g} / \mathrm{kg}$ body weight. For the methanolic extracts of the stem-bark of $M$. senegalensis, the average highest total bilirubin count of $13.1 \mathrm{iu} / \mathrm{l}$ was recorded in rats administered $3 \mathrm{~g} / \mathrm{kg}$ body weight extracts, while the lowest value of $11.8 \mathrm{iu} / \mathrm{l}$ was in rats given both the $6 \mathrm{~g} / \mathrm{kg}$ and $9 \mathrm{~g} / \mathrm{kg}$ body weight extracts. In the water extracts, the highest average count was $11.8 \mathrm{iu} / 1$ in the $9 \mathrm{~g} / \mathrm{kg}$ body weight group, while the lowest value of $10.1 \mathrm{iu} / \mathrm{l}$ in the $6 \mathrm{~g} / \mathrm{kg}$ body weight group. For the methanolic extracts of the leaves of Cassia alata, the average highest total bilirubin count of $10.9 \mathrm{iu} / 1$ was recorded in the $3 \mathrm{~g} / \mathrm{kg}$ body weight treated rats, while the lowest value of $9.0 \mathrm{iu} / \mathrm{l}$ was in the $9 \mathrm{~g} / \mathrm{kg}$ body weight treated group. For the water extracts, the highest average count was $10.4 \mathrm{iu} / \mathrm{l}$ recorded in both the $3 \mathrm{~g} / \mathrm{kg}$ and $9 \mathrm{~g} / \mathrm{kg}$ body weight treated rats, while the lowest value of $9.0 \mathrm{iu} / \mathrm{l}$ in the $6 \mathrm{~g} / \mathrm{kg}$ body weight rats. For the methanolic extracts of the seeds of Cassia alata, the average highest total bilirubin count value was $12.7 \mathrm{iu} / \mathrm{l}$ recorded in the $6 \mathrm{~g} / \mathrm{kg}$ body weight treated rats group, while the lowest value of $9.8 \mathrm{iu} / \mathrm{l}$ was in the $9 \mathrm{~g} / \mathrm{kg}$ body weight treated groups. For the water extracts, the highest total bilirubin average count was $10.9 \mathrm{iu} \mathrm{g} / \mathrm{l}$ in the $9 \mathrm{~g} / \mathrm{kg}$ body weight treated rats, whike the lowest value of $10.1 \mathrm{iu} / \mathrm{l}$ was in the $6 \mathrm{~g} / \mathrm{kg}$ body weight treated rats. Subjecting the result to ANOVA test revealed that these differences are not significant statistically $(\mathrm{P} \leq 0.05)$. The total bilirubin (TBB) values in serum of normal albino rats range between 4 $-21 \mu \mathrm{mol} / 1$ depending on the age and sex according to Giknis and Clifford (2008). These values fall within the standard values except for that of rats in the infected non treated control group which have having a higher values. These difference observed according to El-Sahly, et al. (1985) and Omran, et al. (1988) 
could be due to either, increased haemolysis or iron deficiency that might have occurred during the infection The direct increase in serum bilirubin may be due to the loss of erythrocytes which may arise from the extrusion of schistosomal ova or because of the consumption of blood by schistosomes as might be observed in highest values of infected non-treated control group (Walaa et al., 2001).

Conclusion: The crude methanol and water extracts from the roots, leaves, stem-bark of Maytenus senegalensis as well as that of the leaves and seed of Cassia alata showed varying levels of antischistosomal activities on schistosome infected albino rats. The results obtained from the liver enzyme parameters of the extracts treated rats showed that the $6 \mathrm{~g} / \mathrm{kg}$ body weight had a good potential. However the roots of $M$. senegalensis at the dose of $9 \mathrm{~g} / \mathrm{kg}$ body weight are haemolytic effects and had side effects on the lungs and the seed of Cassia alata can cause hepatomegaly in rats.

\section{REFERENCES}

Abdel-Ghaffar, O; Rawi, SM. and Is'hag, AI (2005): Evaluation Of the curative efficacy of Ro 158843 against mansonian schistosomiasis in albino mice. J. Egypt. Soc. Zool. 47: 15-22.

Abdel-Hadi, AM. and Talaat, M (2000): Histological assessment of tissue repair after treatment of human schistosomiasis. Acta Tropica, 77(1): 91-106.

Amir Al-hroob (2010). Haematological and Biochemical Study on Albino Rats Infected with $70 \pm 10$ Cercariae Schistosoma mansoni. Adv. in Environ.l Biol. 4(2): $220-223$

El-Sahly, AM; El-Tablawy, ZM and Abdel-Rahman, HM (1985): Serum haptoglobin level in hepatosplenic schistosomiasis. J. Egypt. Med. Assoc.68: 151-159

Frances, Fischbach (2002): Common Laboratory and Diagnostic Tests, $3^{\text {rd }}$ Edition Lipincott Publishing Co., Philadelphia, $1000 \mathrm{Pp}$

Giknis, Mary. LA and Clifford, Charles, B (2008): Clinical Laboratory Parameters for Clr: WI (Han) rats. Charles River Laboratories publishing services, Senneville Quebec, 17pp

Hamadto, HA; Kamal, KA;Shaheen, H and Zakaria, MS (1990) Total leukocytic count, eosinophilia and cellular immune response in acute and chronic schistosomiasis. J. Egypt. Soc. Parasit. 20(1): 29-34.

Hutchinson, TH and Dalziel, TM (1968): Flora of West Tropical Africa. Vol.III. Part I. Crown of Agents for
Oversea Governments and Administrations. Nulbank, London, Pp 450 - 489.

John,I; Ezekiel, M; Philbert, $\mathrm{C}$ and Andew,A (2008):Schistosomiasis Transmissionat High Altitude Crater lakes in Western Uganda. Infect. Dis. 8:110

Mohammed, AZ; Edino, ST and Samaila, AA.(2007): Surgical Pathology of Schistosomiasis. J. Nat. Med. Assoc. 99(5):570 - 574

Omran, SA; Aboul-Magd, D; Shalaby, SH; El-Garem, AA and El-Ashmawy, SA (1988). Some aspects of iron metabolism in different stages of schistosomiasis. Egypt. J. Bilhar.10(2): 175-186.

Shurrock, RF (2001): The Schistosomiasis and their Intermediate Hosts. In Mahmood A. A. F. (Ed.) Schistosomiasis. Inperial College Publishing Co., London

Stanfield, DP. and Hopkins, B (1966): A field Guide to the Savannah Trees of Nigeria. Ibadan Press University, 36pp.

Stelma, FF; Talla, I; Sow, S; Kongs, Q; Niang, M; Polma, K ; Deelder, AM and Gryseels, B (1995): Efficacy and side effects of Praziquantel in an epidemic focus of Schistosoma mansoni. Am. J. Trop.Med. and Hyg., 53: $167-170$

Walaa, MS; Ahmed, Walaa A. Moselhy and. Nabil, TM (2015): Bisphenol A Toxicity in Adult Male Rats: Hematological, Biochemical and Histopathological Approach, Global Veterinaria, 14 (2): 228-238.

World Health Organization (WHO, 1980): Epidemiology and Control of Schistosomiasis. WHO technical Report Series. 634 - 635. WHO, Geneva, Switzerland, 84pp

WHO (2003): Efficacy of Oxamniquine and Praziquantel in treatment of Schistosoma mansoni infection: a controlled trial. Bulletin of WHO, 81(3): 190-196.

WHO(2010): Schistosomiasis, Fact Sheet No. 115. http://www. who.int/ mediacenter/ facesheet/fs. $\underline{115 / \mathrm{en} / \text { indexhtml }}$

WHO (2013): Initiative for Vaccine Research (IVR), Parasitic Diseases. W Schistosomiasis Facts Sheets. http:www.who.int/entity/mediacenter/factsheets/fs.1 $\underline{15 \text { en.index.html }}$ 